\title{
Spatial variations in zooplankton diversity in waters contaminated with composite effluents
}

\author{
Subhra Kumar MUKHOPADHYAY ${ }^{1)}$, Buddhadeb CHATTOPADHYAY, Abhishek Roy GOSWAMI* and \\ Asitava CHATTERJEE ${ }^{2)}$ \\ Government College of Engineering and Leather Technology, Block- LB Sector III, Salt Lake City Kolkata-700098 \\ ${ }^{1)}$ Durgapur Government College, J.N Avenue Durgapur 713214, India \\ ${ }^{2)}$ Directorate of Forest, Govt. of West Bengal, Kolkata, India \\ *e-mail corresponding author: rg.abhishek@gmail.com
}

\begin{abstract}
Zooplankton species are cosmopolitan in their clean freshwater habitat and are also found in industrial and municipal wastewaters. The present study records for the first time the aspects of zooplankton diversity in relation to physico-chemical environment of five selected sites of the East Calcutta wetlands, a Ramsar site of Kolkata city, India, heavily contaminated by industrial and municipal wastewaters. The study revealed the occurrence of 22 species of zooplankton, among these 3 species of Cladocera, 2 species of Copepoda, 15 species of Rotifera, and 2 species of Ostracoda were recorded. The copepod Mesocyclops leuckarti was found in all the five sites, rotifers Asplanchna brightwelli, Brachionus angularis, B. calyciflorus and Cladocera Ceriodaphnia cornuta were found in four sites; Moina micrura and Diaphanosoma sarsi were found at three sites. Site wise variation in dominance, diversity, evenness and richness were calculated. Site 1, a fish-pond that stabilized composite wastewater, showed the maximum species richness having 17 species, while Site 2, SWF wastewater carrying canal, showed only 4 species. The calculated Jack 1 values of Sites 1 to 5 were 21.78 , 3.77, 18.63, 12.5 and 16.95 respectively. Shannon-Wiener species diversity index $\left(H^{\prime}\right)$ values were almost similar for all the three relatively less polluted sites viz, Site 1 (1.959), Site 4 (2.010), Site 5 (2.047). However, at highly polluted sites viz., 2 and $3, H^{\prime}$ value of 1.336 and 0.984 respectively, were calculated. Simpson's Dominance index $\left(D_{\text {simp }}\right)$ value was highest at Site $3(0.618)$ indicating maximum dominance, whereas at Site 5 dominance was lowest (0.1680) and diversity was highest. We discuss the role of zooplankton in the amelioration of wastewater.
\end{abstract}

Keywords: East Calcutta wetland, Ramsar site, zooplankton, wastewater-fed fishponds, diversity indices

\section{INTRODUCTION}

Zooplankton species are cosmopolitan in nature and they inhabit all freshwater habitats of the world, including polluted industrial and municipal wastewaters. Zooplankton are not only useful as bioindicators to help us detect pollution load, but are also helpful for ameliorating polluted waters. Comparisons of size structure, fecundity, and reproductive strategies of zooplankters can indicate the nature and extent of pollutant loads (Sarma 1996; Mukhopadhyay et al. 2000). The eastern fringe of Kolkata (formerly Calcutta), has the largest urban wetland, the East Calcutta Wetlands (ECW), a Ramsar site (No. 1208), that covers around 12,500 ha. The area includes 286 wastewater-fed fishponds spread over $3,832.27$ ha (over $30 \%$ of the total wetland area) that produce nearly 10,915 metric tonnes of fish annually (Chattopadhyay et al. 1999). It receives effluents from about 6000 small-scale industrial establishments like tanneries, rubber industries, electroplating industries, pigment manufacturing units, potteries, and battery manufacturing plants. Composite industrial effluent together with municipal wastewater flow down through a web of canals traversing the ECW ecosystem and are finally discharged in Kultigong River, nearly 40 kilome- ters from Kolkata city. A number of vast shallow water bodies receive the bulk of polluted wastewater and are used in pisciculture. ECW ecosystem modifies and traps a broad spectrum of contaminants. From the source to the discharge site the wastewater exhibits substantial reductions in Total Suspended Solids (TSS), Total Dissolved Solids (TDS), total hardness, chloride content, Biochemical Oxygen Demand $\left(\mathrm{BOD}_{5}\right)$ and Chemical Oxygen Demand (COD) (Chattopadhyay et al 2004). Interesting dynamics in the community structure of zooplankton, thriving in wastewater and contaminated waters, have been recently reported from India. The present study is the first attempt to record the changes in the community structure of zooplankton, in a stabilization pond and in wastewater carrying canals along the gradient from the source points down to the confluence site in response to the changing physico-chemical environment.

\section{MATERIALS AND METHODS}

The areas under investigation were located between Dhapa and Kultigong in the ECW (lat. $22^{\circ} 33^{\prime}-22^{\circ} 40^{\circ}$ $\mathrm{N}$; long. $88^{\circ} 25^{\prime}-88^{\circ} 33^{\prime} \mathrm{E}$ ), India. The first sampling station (Site 1) was a fishpond fed by tannery effluent, 
around $1 \mathrm{~km}$ away from the source point of the canal that carried raw composite tannery effluent from Tangra tannery agglomerate, Kolkata. The second station (Site 2) was located at Chowbaga, which is $8 \mathrm{~km}$ from the source point, where the composite tannery effluent was siphoned into the Storm Water Flow (SWF) canal, that is being mixed with the municipal sewage through Ballygunge Drainage Pumping System which carries the bulk effluent load from two other tannery agglomerates (Topsia and Tiljala) and other small-scale industries. The third sampling station (Site 3) was on the SWF canal, near the proposed Calcutta Leather Complex at Karaidanga, around $15 \mathrm{~km}$ away from the source point. Site 4 was located on the same canal near Kultigong lock gate around $40 \mathrm{~km}$ away from the source point. Here SWF meets with the Dry Weather Flow (DWF) canal that principally carries the municipal sewage about 200 metres upstream of Kultigong river. Site 5 was on the DWF at Ghoshpur, $1 \mathrm{~km}$ upstream from Kultigong lock gate. Sampling was done monthly for two years (24 months) between 11.00 and16.00 hours.

From each sampling station 351 of surface water was slowly filtered through a No. 25 bolting silk cloth plankton net for quantitative estimation of plankters. Phytoplankters and Nanozooplankters were studied in live condition. All plankton samples were analysed using Leica DM LB2 microscope fitted with Leica DFC320 camera. Narcotization, preservation and identification of plankters were made using standard references (Ahlstorm 1940; Sharma 1979a; Sharma 1979b;
Michael \& Sharma 1988; Edmondson 1992; Battish 1992).

The chemical parameters of water, including Chloride, Acidity, Alkalinity, Total Hardness, Carbonate hardness, were analyzed on the spot by using EMERCK (Germany) Aquamerk/ Aquaquont water testing kits. COD, BOD, TSS, phosphate $\left(\mathrm{PO}_{4}^{3-}\right)$, nitrate $\left(\mathrm{NO}_{3}^{-}\right)$, sulphide $\left(\mathrm{S}^{2-}\right)$ and metals were analyzed following Eaton et al. 1995. pH, conductivity, TDS and Dissolved Oxygen (DO) were measured potentiometrically on the spot using Multiline P4 (WTW, Germany). Air and water temperature were measured by using multi-user digital thermometer. For statistical computation and community structure analyses, statistical computer software (Statistica for Windows, Version 5.1A, Statsoft Inc., 1996), SPSS (SPSS for Windows, Release 10.0.1 SV, SPSS Inc., 1999) and Community Analysis Package (IRC, UK, 2000) were used.

\section{RESULTS AND DISCUSSION}

Tables 1 and 2 show the mean values (and standard deviation) of different physico-chemical conditions and metal loads recorded from the four sites on the wastewater-carrying canal and from the tannery wastewater fed fishpond. Most of these values, even in the relatively cleaner sites of the wastewater carrying canal and the tannery wastewater-fed fishpond, were much different from those reported from uncontaminated ponds of West Bengal (Sharma 1992; Michael 1968). Zooplankters

Tab. 1. Mean and standard deviation $(\mathrm{N}=24)$ of the physicochemical parameters measured at the study sites.

\begin{tabular}{|c|c|c|c|c|c|c|c|c|c|c|}
\hline & \multicolumn{2}{|c|}{ Site 1} & \multicolumn{2}{|c|}{ Site 2} & \multicolumn{2}{|c|}{ Site 3} & \multicolumn{2}{|c|}{ Site 4} & \multicolumn{2}{|c|}{ Site 5} \\
\hline & Mean & s.d. & Mean & s.d. & Mean & s.d. & Mean & s.d. & Mean & s.d. \\
\hline Air Temp. $\left({ }^{\circ} \mathrm{C}\right)$ & 32.4 & 2.7 & 32.6 & 2.8 & 32.3 & 3.0 & 32.2 & 2.9 & 33.1 & 3.4 \\
\hline Water Temp. $\left({ }^{\circ} \mathrm{C}\right)$ & 31.3 & 4.0 & 30.8 & 4.0 & 30.8 & 3.2 & 30.9 & 3.0 & 29.8 & 3.5 \\
\hline $\mathrm{pH}$ & 7.9 & 0.7 & 7.6 & 0.6 & 7.3 & 0.6 & 7.4 & 0.6 & 7.5 & 0.7 \\
\hline DO $\left(\mathrm{mg} \mathrm{l}^{-1}\right)$ & 6.0 & 1.6 & 0.1 & 0.2 & 0.4 & 0.6 & 4.2 & 2.0 & 4.5 & 1.5 \\
\hline TDS $\left(\mathrm{mg} \mathrm{l}^{-1}\right)$ & 1451 & 686 & 2386 & 1830 & 958 & 358 & 2307 & 2194 & 1753 & 1563 \\
\hline Conductivity (mS) & 2.9 & 1.4 & 4.8 & 3.6 & 1.9 & 0.6 & 4.8 & 4.5 & 3.6 & 3.2 \\
\hline $\operatorname{TSS}\left(\mathrm{mg} \mathrm{l}^{-1}\right)$ & 542 & 378 & 344 & 144 & 499 & 319 & 96 & 36 & 243 & 98 \\
\hline Tot. Acidity $\left(\mathrm{mmol} \mathrm{l}^{-1}\right)$ & 6.3 & 4.1 & 6.3 & 2.7 & 8.1 & 7.9 & 9.7 & 5.4 & 9.0 & 1.8 \\
\hline Tot. Alkalinity $\left(\mathrm{mmol} \mathrm{l}^{-1}\right)$ & 26.7 & 25.6 & 63.6 & 68.5 & 21.7 & 18.6 & 20.6 & 22.5 & 18.6 & 18.6 \\
\hline $\mathrm{CO}_{3}$ Hardness $\left(\mathrm{mg} \mathrm{l}^{-1} \mathrm{CaCO}_{3}\right)$ & 449 & 397 & 528 & 433 & 407 & 417 & 430 & 410 & 315 & 206 \\
\hline Tot. Hardness $\left(\mathrm{mg} \mathrm{l}^{-1} \mathrm{CaCO}_{3}\right)$ & 754 & 825 & 693 & 648 & 641 & 616 & 944 & 890 & 667 & 422 \\
\hline $\mathrm{Cl}^{-}\left(\mathrm{mg} \mathrm{l}^{-1}\right)$ & 988 & 695 & 1621 & 1195 & 726 & 444 & 1627 & 1698 & 1082 & 858 \\
\hline $\mathrm{PO}_{4}^{3-}\left(\mathrm{mg} \mathrm{l}^{-1}\right)$ & 0.9 & 0.7 & 1.8 & 1.2 & 3.3 & 1.1 & 2.4 & 1.6 & 2.4 & 1.1 \\
\hline $\mathrm{NO}_{3}\left(\mathrm{mg} \mathrm{l}^{-1}\right)$ & 43.6 & 29.0 & 41.0 & 31.9 & 34.6 & 31.5 & 36.9 & 28.2 & 41.5 & 26.7 \\
\hline $\mathrm{NO}_{2}^{-}\left(\mathrm{mg} \mathrm{l}^{-1}\right)$ & 9.9 & 7.9 & 4.4 & 0.4 & 4.4 & 0.4 & 4.7 & 0.4 & 7.4 & 2.4 \\
\hline $\mathrm{S}^{2-}\left(\mathrm{mg} \mathrm{l}^{-1}\right)$ & 128.4 & 100.5 & 77.6 & 79.1 & 141.9 & 39.6 & 85.3 & 40.3 & 121.1 & 55.1 \\
\hline $\mathrm{BOD}_{5}\left(\mathrm{mg} \mathrm{l}^{-1}\right)$ & 149 & 77 & 264 & 171 & 95 & 40 & 86 & 37 & 122 & 79 \\
\hline $\mathrm{COD}\left(\mathrm{mg} \mathrm{l}^{-1}\right)$ & 4740 & 4408 & 5602 & 3968 & 3979 & 3785 & 2241 & 2105 & 1642 & 1312 \\
\hline Chlorophyll $a\left(\mathrm{mg} \mathrm{l}^{-1}\right)$ & 38.6 & 0.0 & 18.5 & 6.6 & 8.6 & 3.8 & 12.7 & 3.0 & 21.2 & 6.8 \\
\hline
\end{tabular}


Tab. 2. Mean and standard deviation $(\mathrm{N}=24)$ of the total metal content of the wastewater measured at the study sites.

\begin{tabular}{|c|c|c|c|c|c|c|c|c|c|c|}
\hline & \multicolumn{2}{|c|}{ Site 1} & \multicolumn{2}{|c|}{ Site 2} & \multicolumn{2}{|c|}{ Site 3} & \multicolumn{2}{|c|}{ Site 4} & \multicolumn{2}{|c|}{ Site 5} \\
\hline & Mean & s.d. & Mean & s.d. & Mean & s.d. & Mean & s.d. & Mean & s.d. \\
\hline Chromium (mg l-1) & 0.014 & 0.031 & 0.263 & 0.372 & 0.067 & 0.188 & 0.029 & 0.062 & 0.058 & 0.125 \\
\hline Lead $\left(\mathrm{mg} \mathrm{l}^{-1}\right)$ & 0.463 & 0.124 & 0.408 & 0.088 & 0.336 & 0.105 & 0.359 & 0.101 & 0.281 & 0.097 \\
\hline Copper $\left(\mathrm{mg} \mathrm{l}^{-1}\right)$ & 0.661 & 0.338 & 0.211 & 0.025 & 0.834 & 0.631 & 0.897 & 0.439 & 1.262 & 1.091 \\
\hline Zinc $\left(\mathrm{mg} \mathrm{l}^{-1}\right)$ & 0.112 & 0.058 & 0.215 & 0.035 & 0.136 & 0.035 & 0.194 & 0.026 & 0.267 & 0.050 \\
\hline Manganese $\left(\mathrm{mg} \mathrm{l}^{-1}\right)$ & 2.358 & 1.651 & 1.142 & 0.114 & 1.814 & 1.237 & 2.654 & 1.657 & 1.925 & 0.765 \\
\hline Magnesium $\left(\mathrm{mg} \mathrm{l}^{-1}\right)$ & 83.55 & 20.53 & 103.4 & 4.17 & 152.2 & 52.69 & 50.89 & 38.97 & 177.6 & 94.61 \\
\hline Iron $\left(\mathrm{mg} \mathrm{l}^{-1}\right)$ & 2.162 & 0.756 & 1.978 & 0.999 & 2.500 & 1.317 & 1.800 & 0.673 & 2.305 & 1.272 \\
\hline
\end{tabular}

were represented by fifteen rotifers, two copepods, three cladocerans and two ostracoda species. Tables 3 demonstrates the succession of zooplankters along the study sites starting from the source down to final discharge point. The successional sequence was as follows: sessile Rotifera (Site 2) $\rightarrow$ pelagic Rotifera (Site 3) $\rightarrow$ pelagic Rotifera and Microcrustaceans (Site 4 and 5). Wetzel (2001) pointed out that rotifers commonly appear early in the succession of zooplankton communities and are succeeded by microcrustaceans. Rotifers were usually suppressed by cladocerans through exploitative competition for shared, limiting food resources. In cleaner water, the abundance and diversity of organisms with complex life history strategies increased.

\subsection{Rotifers: Nature's water purifiers}

Rotifers, the tiny wheel animalcules, are considered nature's water purifiers because they perform an important cleanup service in the still or slow-moving waters they inhabit. Sharma (1992) made a detailed account of the systematics and ecology of freshwater rotifers of West Bengal, but investigations on rotifers inhabiting industrial or municipal wastewater of India are scant (Arora 1961; Chandra \& Krishna 1983; Patil \& Harshey 1983; Sharma 1986; Saksena \& Kulkarni 1986; Das \& Dutta 1998). As an age-old practice, raw composite tannery effluents are stabilised in a number of tanks for the purpose of pisciculture in the ECW ecosystem. Rotifers are present in such tanks and in the wastewater carrying canal and perform the excellent function of combating organic debris load.

The presence of fifteen-rotifer species in waters with a high chloride concentration (725-1627 $\left.\mathrm{mg} \mathrm{l}^{-1}\right)$ indicates their euryhaline nature. Interestingly, these rotifers were also observed to grow when the $\mathrm{pH}$ was in the range of 7.3-7.9. Species that reached large population sizes in the slightly acidic or near-neutral waters included: Asplanchna intermedia, A. brightwelli, Brachionus calyciflorus dorcas and Filinia longiseta. Sharma (1992) also records the occurrence of $A$. priodonta, $A$. brightwelli and B. calyciflorus in acidic and neutral waters. B. calyciflorus dorcas f. spinosa flourished in both acidic (pH 6.9) and alkaline (pH 8.6) conditions in the present study, thus exhibiting a wide range of $\mathrm{pH}$ tolerance. DO (0.1 to $\left.6.0 \mathrm{mg} \mathrm{l}^{-1}\right)$ showed little effect on the rotiferan community. Both illoricate rotifers and rotifers as a whole exhibited significant $(\mathrm{P}<0.05)$ positive correlation with $\mathrm{DO}\left(\mathrm{r}=0.80\right.$ and 0.81 respectively), $\mathrm{NO}_{2}^{-}(\mathrm{r}$ $=0.90$ and 0.89 respectively $)$ and $\mathrm{S}^{2-}(\mathrm{r}=0.84$ and 0.83 respectively) and significant $(\mathrm{P}<0.05)$ negative correlation with conductivity ( $\mathrm{r}=-0.98$ in both cases) and Chloride ( $r=-0.90$ and -0.88 respectively). Correlation coefficient values are given in Table 4.

The significant positive correlation between rotifers and $\mathrm{S}^{2-}$ in the present study is interesting. The reduction of sulphate $\left(\mathrm{SO}_{4}^{2-}\right)$ to $\mathrm{S}^{2-}$, some of which is lost to the sediment as insoluble metallic sulphides, and the oxidation of $\mathrm{H}_{2} \mathrm{~S}$ to $\mathrm{SO}_{4}{ }^{2-}$ both play a significant role in the modification of conditions for wastewater that is contaminated with proteinaceous material. A number of sulphate-reducing bacteria are heterotrophic and anaerobic and use the sulphur compounds during oxidative metabolism. Sulphur-reducing bacteria on the other hand, are obligate anaerobes and produce oxygen from sulphate. These two kinds of bacteria, along with sulphur-oxidising bacteria, grow abundantly in wastewater that is rich in tannery effluent (van Groenestijn et al. 1999) and encourage the growth of both protozoa and rotifers along the food chain.

Freshwater aquaculture ponds of the state of West Bengal are known to harbor a variety of rotiferan species. In a fishpond at Barrackpore, West Bengal, as many as 30 species were recorded (Michael 1968), and in a similar pond 18 species were reported (Sharma 1992). In contrast, throughout the present study period, the presence of only 7-9 species, at low densities in the component populations, categorically indicates the presence of significant toxicants that limit species diversity and density. Even in such adverse physico-chemical environment, three brachionids, viz., Brachionus caudatus personatus (density $13.2 \pm 12.311$ nos. ${ }^{1^{-1}}$ ), B. calyciflorus dorcas f. spinosa (density $72.6 \pm 32.650$ nos. $1^{-1}$ ) and $B$. quadridentatus cluniorbicularis (density $114.5 \pm$ 
Tab. 3. Abundance of zooplanktonic organisms in the sampling sites (Number of organisms $x ~^{-1} \pm \mathrm{sd}$ ). In parenthesis are the minimum and maximum value.

\begin{tabular}{|c|c|c|c|c|c|}
\hline & Site 1 & Site 2 & Site 3 & Site 4 & Site 5 \\
\hline \multicolumn{6}{|l|}{ ROTIFERA } \\
\hline $\begin{array}{l}\text { Asplanchana } \\
\text { intermedia }\end{array}$ & $\begin{array}{c}9.4 \pm 5.9 \\
(0.0-18.4)\end{array}$ & - & $\begin{array}{c}0.7 \pm 2.1 \\
(0.0-9.6)\end{array}$ & - & $\begin{array}{l}19.9 \pm 21.4 \\
(1.5-86.1)\end{array}$ \\
\hline A. brightwelli & $\begin{array}{l}42.1 \pm 55.2 \\
(0.0-163)\end{array}$ & - & $\begin{array}{l}0.3 \pm 1.3 \\
(0.0-6.2)\end{array}$ & $\begin{array}{c}1.8 \pm 4.3 \\
(0.0-15.3)\end{array}$ & $\begin{array}{c}4.6 \pm 5.8 \\
(0.1-18.7)\end{array}$ \\
\hline $\begin{array}{l}\text { Brachionus } \\
\text { candatus personatus }\end{array}$ & $\begin{array}{l}13.2 \pm 12.3 \\
(0.0-40.2)\end{array}$ & - & $\begin{array}{c}2.8 \pm 4.2 \\
(0.0-13.5)\end{array}$ & $\begin{array}{c}2.2 \pm 5.6 \\
(0.0-24.7)\end{array}$ & - \\
\hline B. angularis & $\begin{array}{l}0.8 \pm 0.76 \\
(0.0-2.2)\end{array}$ & - & $\begin{array}{c}1.8 \pm 4.2 \\
(0.0-15.1)\end{array}$ & $\begin{array}{c}1.6 \pm 2.7 \\
(0.0-11.6)\end{array}$ & $\begin{array}{c}3.1 \pm 5.2 \\
(0.0-18.3)\end{array}$ \\
\hline $\begin{array}{l}\text { B. calyciflorus } \\
\text { dorcas f. spinosa }\end{array}$ & $\begin{array}{l}72.6 \pm 32.6 \\
(2.6-122)\end{array}$ & - & $\begin{array}{c}126 \pm 90.8 \\
(12.5-318)\end{array}$ & $\begin{array}{c}3.0 \pm 3.8 \\
(0.0-16.1)\end{array}$ & $\begin{array}{c}62.4 \pm 55.4 \\
(7.1-182.6)\end{array}$ \\
\hline $\begin{array}{l}\text { B. quadridentatus } \\
\text { cluniorbicularis }\end{array}$ & $\begin{array}{l}114 \pm 101 \\
(0.0-274)\end{array}$ & - & - & - & $\begin{array}{c}8.3 \pm 16.6 \\
(0.0-67.1)\end{array}$ \\
\hline B. plicatilis & $\begin{array}{c}0.2 \pm 0.4 \\
(0.0-1.4)\end{array}$ & - & $\begin{array}{c}1.8 \pm 4.9 \\
(0.0-18.1)\end{array}$ & $\begin{array}{c}0.9 \pm 2.2 \\
(0.0-10.3)\end{array}$ & - \\
\hline B. bidentata & - & - & $\begin{array}{c}2.2 \pm 5.3 \\
(0.0-25.2)\end{array}$ & $\begin{array}{c}6.6 \pm 7.9 \\
(0.2-28.1)\end{array}$ & - \\
\hline B. rubens & - & - & $\begin{array}{c}4.7 \pm 11.5 \\
(0.0-48.2)\end{array}$ & - & - \\
\hline B. falcatus & $\begin{array}{c}7.1 \pm 17.5 \\
(0.0-82.5)\end{array}$ & - & - & - & $\begin{array}{l}11.5 \pm 17.2 \\
(0.0-53.2)\end{array}$ \\
\hline Keratella tropica & $\begin{array}{c}0.6 \pm 0.8 \\
(0.0-2.4)\end{array}$ & $\begin{array}{l}1.1-2.2 \\
(0.0-8.2)\end{array}$ & $\begin{array}{c}1.0-2.6 \\
(0.0-2.6)\end{array}$ & - & $\begin{array}{c}1.0-1.7 \\
(0.0-5.1)\end{array}$ \\
\hline Filinia opoliensis & $\begin{array}{l}21.4 \pm 38.1 \\
(0.0-132)\end{array}$ & - & $\begin{array}{c}1.4 \pm 2.2 \\
(0.0-7.0)\end{array}$ & - & $\begin{array}{c}9.1 \pm 15.6 \\
(0.0-47.3)\end{array}$ \\
\hline F. longiseta & - & - & - & - & $\begin{array}{c}3.3 \pm 3.7 \\
(0.0-11.8)\end{array}$ \\
\hline Philodina citrina & - & $\begin{array}{l}1.2- \pm 3.6 \\
(0.0-14.2)\end{array}$ & - & - & - \\
\hline Scaridium longicaudum & $\begin{array}{c}0.2 \pm 0.8 \\
(0.0-4.1)\end{array}$ & $\begin{array}{c}0.8 \pm 2.1 \\
(0.0-8.5)\end{array}$ & - & - & $\begin{array}{l}0.5 \pm 1.2 \\
(0.0-4.6)\end{array}$ \\
\hline \multicolumn{6}{|l|}{ COPEPODA } \\
\hline Mesocyclops leuckarti & $\begin{array}{r}6.6 \pm 16.2 \\
(0.0-66.2)\end{array}$ & $\begin{array}{c}0.5 \pm 1.2 \\
(0.0-3.4)\end{array}$ & $\begin{array}{c}2.1 \pm 3.9 \\
(0.0-13.2)\end{array}$ & $\begin{array}{c}14.5 \pm 8.7 \\
(2.0-31.9)\end{array}$ & $\begin{array}{c}93.6 \pm 64.1 \\
(6.5-191.3)\end{array}$ \\
\hline M. hyalinus & $\begin{array}{c}3.1 \pm 4.5 \\
(0.0-12.7)\end{array}$ & - & - & - & $\begin{array}{c}1.9 \pm 3.5 \\
(0.0-12.4)\end{array}$ \\
\hline \multicolumn{6}{|l|}{ CLADOCERA } \\
\hline Moina micrura & $\begin{array}{c}1.1 \pm 18.2 \\
(0.0-69.1)\end{array}$ & - & - & $\begin{array}{c}5.4 \pm 4.4 \\
(0.2-13.5)\end{array}$ & $\begin{array}{c}36.9 \pm 40 \\
(1.5-133)\end{array}$ \\
\hline Ceriodaphnia cornuta & $\begin{array}{c}1.9 \pm 5.7 \\
(0.0-26.5)\end{array}$ & - & $\begin{array}{c}0.2 \pm 0.4 \\
(0.0-1.2)\end{array}$ & $\begin{array}{c}1.1 \pm 1.8 \\
(0.0-6.8)\end{array}$ & $\begin{array}{c}6.1 \pm 11 \\
(0.0-41.7)\end{array}$ \\
\hline Diaphanosoma sarsii & $\begin{array}{c}0.4 \pm 1.1 \\
(0.0-3.9)\end{array}$ & - & $\begin{array}{c}0.5 \pm 0.9 \\
(0.0-2.8)\end{array}$ & - & $\begin{array}{l}12.4 \pm 14.3 \\
(0.0-55.9)\end{array}$ \\
\hline \multicolumn{6}{|l|}{ OSTRACODA } \\
\hline Cyclocypris globosa & - & - & $\begin{array}{l}13.7 \pm 14.2 \\
(0.2-45.1)\end{array}$ & $\begin{array}{c}0.8 \pm 0.7 \\
(0.0-1.9)\end{array}$ & - \\
\hline Cyprinotus dentatus & $\begin{array}{l}79.2 \pm 77.6 \\
(0.0-210)\end{array}$ & - & - & $\begin{array}{c}6.4 \pm 7.6 \\
(0.2-29.6)\end{array}$ & $\begin{array}{l}38.2 \pm 28.2 \\
(6.6-99.0)\end{array}$ \\
\hline
\end{tabular}


100.656 nos. $~^{-1}$ ) thrived in large numbers in the wastewater fed fish pond (Site 1). Thus, these species could be considered very tolerant species, as far as the present ecotoxicants were concerned. B. calyciflorus dorcas $\mathrm{f}$. spinosa also appeared in even larger numbers in the more troubled waters of Site 3 (density $126.1 \pm 90.791$ nos. $1^{-1}$ ). Two illoricate forms, viz, A. intermedia and A. brightwelli, thrived in larger numbers at Sites 1 and 5, which share a much more similar physico-chemical regime. Several toxicants in the environment are known to induce rapid parthenogenetic development while reduced sexual development in different rotifer species, even at low concentrations (Snell et al. 1999). Parthenogenetic swarms of brachionids and, at times, of A. brightwelli corroborate such findings in the stabilisation ponds fed by tannery wastewater in the present study.

Forbes (1999) pointed out that parthenogenetically reproducing clones of cladocerans and rotifers offer several advantages, the most important of which is the identification and quantification of the role of genetic factors in controlling responses to toxicants, under stressful situations. Snell et al. (1999) reported a toxicant-induced reduction in rotiferan population growth rate. It was observed that the most serious consequence of such reduced population growth rate was a reduction in resting egg production.

Rotifers were common in the samples collected from Sites 1, 3, 4 and 5. Three rotifer species, viz., Keratella tropica, Philodina citrina and Scaridium longicaudum appeared in small number in the samples collected from Site 2. A very small population of Scaridium longicaudum was also noted from Sites 1 and 5 (Tab. 3). Dominant rotifer species were Asplanchna intermedia, A. brightwelli, B. calyciflorus dorcas f. spinosa and $B$. quadridentatus cluniorbicularis. Occurrence of these clean-water species in high abundance in wastewater indicates their tolerance to a wide range physico-chemical factors. Sharma (1992) reported the alkaline preference of B. angularis, B. caudatus and B. calyciflorus, but in the present study they grew in the mean $\mathrm{pH}$ range of $7.32 \pm 0.586-7.91 \pm 0.690$.

\subsection{Micro crustaceans: grazing - predation - detritivory}

Six microcrustacean species, comprising of two predatory Copepods, three grazer Cladocerans and two detritivore Ostracods appeared in the wastewater (Tab. 3). Mesocyclops leuckarti was the only copepod present in all the sampling stations. In sites 1 and $5 \mathrm{M}$. hyalinus also appeared along with $M$. leuckarti. Collections from these sites also contained 3 cladoceran species; of these, Moina micrura was the most abundant. The other two species, Ceriodaphnia cornuta and Diaphanosoma sarsi were present in small numbers at Sites 1 and 5. C. cornuta was also present at low abundance in Site 4 while a similarly low density of $D$. sarsi was noted from site 3. Two species of ostracoda, viz., Cyclocypris globosa and Cyprinotus dentatus were observed in the collected samples. Ostracods are omnivorous and feed on bacteria, algae, detritus and other microorganisms by means of filtration (Edmondson 1992). They are mostly active on the surface of the sediment and as their population flourished, the species appeared in the littoral samples. Cyclocypris globosa was present at Sites 3 and 4 whereas Cyprinotus dentatus was present Sites 1, 4 and 5 . Important physico-chemical factors influenced the microcrustacean population fluctuation, including DO, conductivity, chloride, nitrite $\left(\mathrm{NO}_{2}^{-}\right), \mathrm{S}^{2-}, \mathrm{COD}, \mathrm{Cu}$ and $\mathrm{Mg}$. Significant negative correlations were observed between ostracods and conductivity $(\mathrm{r}=-0.98 ; \mathrm{P}<0.05)$ and chloride $(r=-0.89 ; \mathrm{P}<0.05)$. Significant positive correlations were observed between ostracods and $\mathrm{NO}_{2}$ $(\mathrm{r}=0.90 ; \mathrm{P}<0.05)$ and $\mathrm{S}^{2-}(\mathrm{r}=0.89 ; \mathrm{P}<0.05)$. Total copepods and cladocerans exhibited a significant negative correlation with COD ( $\mathrm{r}=-0.78$ and -0.74 respectively; $\mathrm{P}<0.05)$ but positive correlations with $\mathrm{Cu}(\mathrm{r}=$ 0.84 for both cases; $\mathrm{P}<0.05)$ and $\mathrm{Mg}(\mathrm{r}=0.75$ and 0.73 respectively; $\mathrm{P}<0.05)$. Both correlations and multiple regression analyses are given in Table 4.

\subsection{Zooplankton community structure analysis}

Site-wise variations in dominance, diversity, evenness, richness and other indices of community structure are given in Tables 5 and 6. Estimating the total or real number of species, i.e., species richness, including those that were not sampled, in a community is a crucial task, especially when the habitat is in a stressful situation. For this purpose, first-order Jack Knife Estimate (JACK1) of species richness was employed to resample the observed species and to relate the estimated species richness to a higher sample size. JACK 1 values calculated for the five sites were as follows: Site 1 - 21.78, Site 2- 3.77 Site 318.63 and Site 4- 12.5 and Site 5- 16.95. Therefore, the value was lowest for the most polluted sampling station (Site 2) and highest for the stabilized fishpond (Site 1). Shannon-Wiener species diversity index $\left(H^{\prime}\right)$, based mainly on the proportional species abundance, was almost similar for all the three sites, viz., Site 1 (1.959), Site 4 (2.010) and Site 5 (2.047). In Site 2 and Site 4 the calculated values were 1.336 and 0.984 respectively. At the most stressful site (site 2), $H^{\prime}$ value was slightly higher than Site 3, though only four species occurred at the former site. Pielou's index of evenness $\left(J^{\prime}\right)$ was highest in Site $2(0.964)$ followed by Site $4(0.838)$, Site 5 $(0.738)$ and Site $1(0.691)$ while the lowest was recorded in Site 3 (0.363). Therefore, except Site 3, the $J^{\prime}$ values for all other sites were within a comparable range.

Simpson's dominance index $\left(D_{\text {SIMP }}\right)$, which is also based on proportional abundance like $H^{\prime}$, showed quite contrasting values to those for $H^{\prime}$. $D_{\text {SIMP }}$ value was highest for Site $3(0.618)$ indicating maximum dominance at the site with minimum diversity, as reflected by the $H^{\prime}$ value. In contrast, dominance was lowest at Site 5 
Tab. 4. Correlation coefficients (significant at $\mathrm{P}<0.05$ ) between the zooplankton communities and the physicochemical environment of their habitat (*marked correlations were significant).

\begin{tabular}{lcccccccc}
\hline & $\mathrm{D} .0$ & $\mathrm{C} 0 \mathrm{Nd}$ & $\mathrm{Cl}$ & $\mathrm{NO}_{2}^{-}$ & $\mathrm{S}^{2-}$ & $\mathrm{COD}$ & $\mathrm{Cu}$ & $\mathrm{Mg}$ \\
\hline Illoricate Rotifera & $0.80^{*}$ & $-0.98^{*}$ & $-0.90^{*}$ & $0.90^{*}$ & $0.84^{*}$ & -0.14 & 0.37 & 0.12 \\
Total Rotifera & $0.81^{*}$ & $-0.98^{*}$ & $-0.88^{*}$ & $0.89 *$ & $0.83^{*}$ & -0.14 & 0.38 & 0.07 \\
Copepoda & 0.49 & -0.46 & -0.59 & 0.42 & 0.57 & $-0.78^{*}$ & $0.83^{*}$ & $0.74 *$ \\
Cladocera & 0.58 & -0.59 & -0.69 & 0.53 & 0.67 & $-0.74 *$ & $0.83^{*}$ & $0.73^{*}$ \\
Ostracoda & $0.84^{*}$ & $-0.98^{*}$ & $-0.89 *$ & $0.90 *$ & $0.84^{*}$ & -0.20 & 0.43 & 0.09 \\
Total Zooplankton & $0.85^{*}$ & $-0.98^{*}$ & $-0.95^{*}$ & $0.90 *$ & $0.89 *$ & -0.39 & 0.60 & 0.31 \\
\hline
\end{tabular}

Tab. 5. Different indices to comment on the community structure of the study sites.

\begin{tabular}{|c|c|c|c|c|c|}
\hline Diversity indices & Site-1 & Site-2 & Site-3 & Site-4 & Site-5 \\
\hline $\begin{array}{l}\text { Species Number Estimate } \\
{\left[\text { Jack } 1=O S+r_{I}(n-1) / n\right.}\end{array}$ & 21.78 & 3.77 & 18.63 & 12.5 & 16.95 \\
\hline $\begin{array}{l}\text { Shannon-Wiener Species } \\
\text { Diversity Index }\end{array}$ & 1.959 & 1.336 & 0.984 & 2.010 & 2.047 \\
\hline$\left[H^{\prime}=-\sum_{\mathrm{i}=1}^{o s} p i \ln p i\right]$ & & & & & \\
\hline Pielou's Evenness Index & 0.691 & 0.964 & 0.363 & 0.838 & 0.738 \\
\hline$\left[J=\frac{H^{\prime}}{\ln O S}\right]$ & & & & & \\
\hline Margalef's Richness Index & 2.688 & 2.342 & 2.757 & 2.638 & 2.611 \\
\hline$\left[D_{M A R G}=\frac{O S-1}{\ln \mathrm{N}}\right]$ & & & & & \\
\hline $\begin{array}{l}\text { Simpson's Dominance Index } \\
{\left[H_{S I M P}=\sum_{i=1}^{o s}(p i)^{2}\right]}\end{array}$ & 0.185 & 0.273 & 0.618 & 0.176 & 0.168 \\
\hline
\end{tabular}

(0.168) where diversity was maximum (2.047). Although both Shannon measures and Simpson's index consider the proportional abundance of species, $H^{\prime}$ is more sensitive to rare species and $D_{\text {SIMP }}$ puts more emphasis on the common species. Therefore, these indices point out the occurrence of many rare species in
Sites 1, 4 and 5, but not at Site 3. Margalef's richness index $\left(D_{M A R G}\right)$, which considers both abundance and species numbers, varied between 2.342 and 2.757. The highest $D_{M A R G}$ value of 2.757 was calculated at Site 3 , followed by Site 1 (2.688), Site 4 (2.638) and Site 5 (2.611) (Tab. 5). All these sites harboured a good number of 
Tab. 6. Different similarity indices to compare the community structure of the study sites

\begin{tabular}{lccccccccc}
\hline & \multicolumn{2}{c}{ Site-2 } & \multicolumn{2}{c}{ Site-3 } & \multicolumn{2}{c}{ Site-4 } & \multicolumn{3}{c}{ Site-5 } \\
\hline & $S_{J}$ & $S_{M}$ & \multicolumn{1}{c}{$S_{J}$} & $S_{M}$ & \multicolumn{1}{c}{$S_{J}$} & $S_{M}$ & $S_{J}$ & $S_{M}$ \\
Site-1 & 0.286 & 0.0003 & 0.750 & 0.426 & 0.642 & 0.071 & 0.910 & 0.467 \\
Site-2 & & & 0.210 & 0.0003 & 0.132 & 0.0005 & 0.300 & 0.006 \\
Site-3 & & & & & & 0.692 & 0.054 & 0.646 & 0.500 \\
Site-4 & & & & & & & & 0.518 & 0.240 \\
\hline
\end{tabular}

Jaccard Similarity Index

$$
\begin{aligned}
& {\left[S_{J}=\frac{2 \mathrm{a}}{\text { OStot }}\right]} \\
& \text { Morisita's Similarity Index } \\
& {\left[S_{M}=\frac{2 i \mathrm{xi} 1 \mathrm{xi} 2}{\mathrm{xi}^{2} 1+\mathrm{xi}^{2} 2}\right]}
\end{aligned}
$$

Where $x_{i} 1, x_{i} 2=$ densities of species I at sites $1 \& 2 ; a=$ co-occurring species; OStot $=$ total number species in both sites, $i$ was the species of $i^{\text {th }}$ kind.

zooplankton species. When comparison between sites was made by using quantitative presence-absence type, Jaccard similarity index $\left(S_{J}\right)$ (Tab. 6), Site 1 and Site 5 showed maximum similarity $\left(S_{J}=0.910\right)$ whereas low similarity $\left(S_{J}=0.132\right)$ was calculated between site 2 and Site 4. $S_{J}$ values were also fairly high for the comparisons between Site 1 and Site $3\left(S_{J}=0.750\right)$ and between Site 3 and Site 4 communities $\left(S_{J}=0.692\right)$. Morisita's similarity index $\left(S_{M}\right)$, based on meristic data (i.e., counts of individuals referring quantitative indices), showed high values for the comparison between Site 1 and Site $5\left(S_{M}=0.467\right)$ and low values for the comparison between Site 1 and Site $2\left(S_{M}=0.0003\right)$ and between Site 2 and Site $3\left(S_{M}=0.0003\right)$. Therefore, from the qualitative standpoint, tannery wastewater stabilisation pond was much similar to the sites located at farthest stations on SWF and DWF canals but quantitatively speaking, communities at all the sites, except the Site 2 with much toxic load, were much more similar.

Index of dominance dropped from 0.618 at Site 3 to 0.168 at Site 5 indicating lower environmental stress at the later site. In fact, Sites 1, 4 and 5 all showed considerably lower values (than in the remaining sites) indicating a less stressful situation. Likewise, Shannon index of general diversity more than doubled from Site 3 (0.984) to Site 5 (2.047). Evenness and richness indices also showed the same trend, indicating a gradual improvement of the abiotic environment from Site 2 through to Site 4 . However, density and diversity of the planktonic organisms, even at distant sites of 4 and 5, were significantly lower compared to the reports from clean uncontaminated waters (Michael 1968; Sharma 1992). This definitely indicated the presence of stressful physico-chemical environment even at the final dis- charge site of the canal (Sites 4 and 5) where there was considerable natural abatement of most of the toxicants. Hierarchical cluster analysis of the study sites was done on the basis of the different limnochemical conditions (Fig 1). Dendrograms constructed using nearest neighbour method showed that the Site 2 was quite separate from the two different clusters composed of Site 1-Site 3 and Site 4-Site 5 indicating their comparable physicochemical ambience. Hierarchical cluster analysis of the study sites made based on the abundance of the zooplankton species in the study sites (Fig. 2) revealed a comparable picture. As Site 2 carried the highest loads of contaminants, it was farthest from all the clusters in the dendrogram. Sites 1, 3 and 5 were comparatively cleaner, and harbored zooplankton at comparable densities and richness.

Correlation coefficient values (significant at $\mathrm{P}<0.05$ ) between the diversity indices and metal content in the ambient environment are presented in Table 7. Interestingly, $\mathrm{Cr}$ and $\mathrm{Zn}$ showed significant negative correlation with Species Number Estimate (Jack1) and Margalef's richness index while significant positive correlation with Pielou's evenness index indicating that these metals, when abundant in ambient water, had a negative impact on the zooplanktonic diversity and only the tolerant opportunists grew in contaminated waters. $\mathrm{Pb}$ also exhibited similar result, although not significant at $\mathrm{P}<0.05$. Contrastingly, $\mathrm{Cu}$ and $\mathrm{Mn}$ showed significant positive correlation with Jack1 and Margalef indices and a weak negative correlation with Pielou's evenness index. $\mathrm{Mg}$ and $\mathrm{Fe}$ also exhibited similar results, although the correlation coefficient values were insignificant in all cases. Although most of the trace metal micronutrients like $\mathrm{Cu}, \mathrm{Zn}, \mathrm{Fe}$, and $\mathrm{Mn}$ were in 
Dendrogram using Average Linkage (Nearest neighbour)

Rescaled Distance Cluster Combine

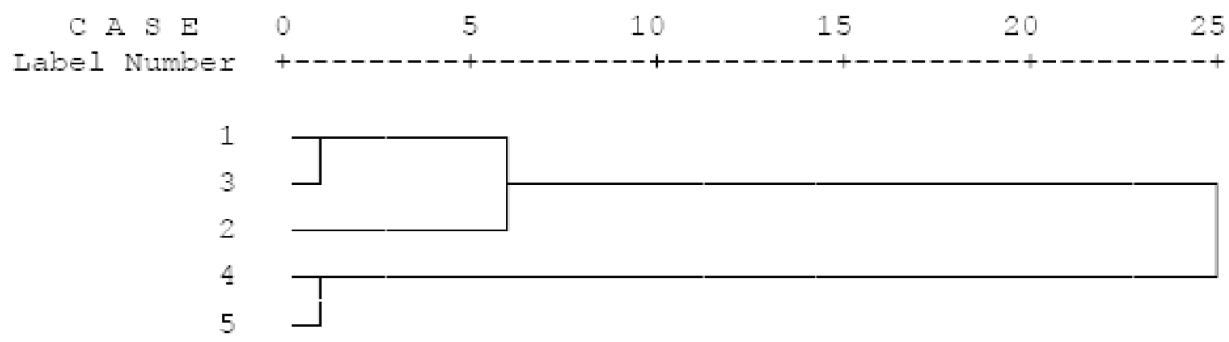

$1=$ Site $1 ; 2=$ Site $2 ; 3=$ Site $-3 ; 4=$ Site $-4 ; 5=$ Site -5

Fig. 1. Hierarchical cluster analysis of the selected study sites depending on the limnochemical conditions.

Dendrogram using Average Linkage (Nearest neighbour)

Rescaled Distance Cluster Combine

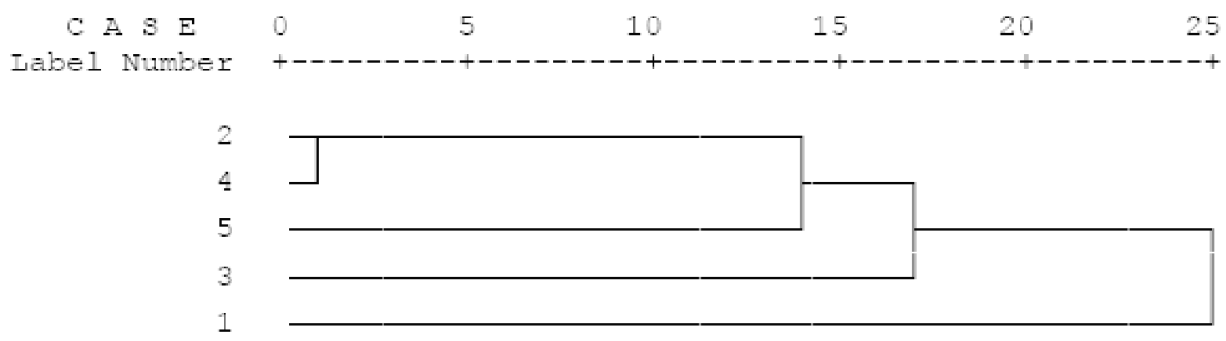

$1=$ Site $1 ; 2=$ Site $2 ; 3=$ Site $-3 ; 4=$ Site $-4 ; 5=$ Site- 5

Fig. 2. Hierarchical cluster analysis of the sites depending on the richness and abundance of zooplankton species in the study sites.

organic complexes, a large fraction of $\mathrm{Zn}$ usually remained in ionic form or weak complexes (Wetzel 2001). Thereby, a difference between $\mathrm{Zn}$ and other bioactive trace elements were observed to influence the zooplankton community structure differently. Most $\mathrm{Pb}$ was also reported to be adsorbed to particle surfaces and thereby exhibited weak correlations as compared to $\mathrm{Cr}$ and $\mathrm{Zn}$ in the present study. Wetzel (2001) reviewed the effects of trace metals on plankton community and it was important to note that the relative concentrations of trace elements had a significant effect on the competitive abilities of the plankton.

\section{CONCLUSION}

The ECW is able to transform and trap a wide range of contaminants. The present study records the remarkable decrease in TSS (72\%), TDS (59\%) and chlorides
(55\%) between the wastewater source point (Site 2) and the final discharge site (Site 4). DO profile increased dramatically from $0.10 \mathrm{mg} \mathrm{l}^{-1}$ at Site 2 to $4.24 \mathrm{mg} \mathrm{l}^{-1}$ at Site 4. Site 1, the wastewater-fed fish pond, had normal DO level (6.01 $\left.\mathrm{mg} \mathrm{l}^{-1}\right)$ for fish development, while Site 4 and Site 5 attained DO values 4.24 and $4.53 \mathrm{mg} \mathrm{l}^{-1}$ respectively, the limit of the fish tolerance by natural processes of stabilization. Decreases in BOD and COD values were $67 \%$ and $60 \%$ respectively. Such changes definitely indicate the cost-effective ameliorative role of the wetland ecosystem proving the excellent efficiency of the natural stabilization of wastewater. At about 30 $\mathrm{km}$ down the source point, we noticed a number of water dependent avifauna around the study sites. From these regions different oligosaprobic fauna like, dragonflies, their nyaads, bloodworms and aquatic beetles were also found. Plankters played a major role in the amelioration processes through degradation of the suspended solids 
Tab. 7. Correlation coefficients (significant at $\mathrm{P}<0.05$ ) between the diversity indices and metal content in the ambient environment (*marked correlations were significant).

\begin{tabular}{lccccc}
\hline & $\begin{array}{c}\text { Jack1 } \\
\text { Estimate }\end{array}$ & $\begin{array}{c}\text { Shannon } \\
\text { Index }\end{array}$ & $\begin{array}{c}\text { Pielou's } \\
\text { Index }\end{array}$ & $\begin{array}{c}\text { Margalef's } \\
\text { Index }\end{array}$ & $\begin{array}{c}\text { Simpson's } \\
\text { Index }\end{array}$ \\
\hline $\mathrm{Cr}$ & $-0.87^{*}$ & $-0.50^{*}$ & $0.49^{*}$ & $-0.90^{*}$ & 0.11 \\
$\mathrm{~Pb}$ & -0.03 & 0.001 & 0.25 & -0.19 & -0.18 \\
$\mathrm{Cu}$ & $0.60^{*}$ & $0.46^{*}$ & -0.38 & $0.64^{*}$ & -0.11 \\
$\mathrm{Zn}$ & $-0.50^{*}$ & 0.31 & $0.53^{*}$ & $-0.52^{*}$ & -0.42 \\
$\mathrm{Mn}$ & $0.59^{*}$ & $0.64^{*}$ & -0.15 & $0.68^{*}$ & -0.34 \\
$\mathrm{Mg}$ & 0.23 & -0.29 & $-0.47^{*}$ & 0.13 & 0.39 \\
$\mathrm{Fe}$ & $0.58^{*}$ & $-0.46^{*}$ & $-0.84^{*}$ & $0.51^{*}$ & $0.66^{*}$ \\
\hline
\end{tabular}

and progressive utilization and transformation of the nutrients. Rotifers, both sessile and pelagic species, degraded TSS, releasing nutrient in one hand and increasing light penetration on the other and thereby augmented phytoplankton productivity and consequently improved DO profile. Such series of changes are important in amelioration processes operating in the wastewater carrying canal (Koteswari \& Ramanibai 2004). Despite the presence of high nutrient load, different other chemical factors might have been responsible to check the excess growth of autotrophs, leading to eutrophication. In addition to the remarkable ameliorative capacity of the ECW, treating about $1 / 3$ of the Kolkata city's wastewater (estimated at 68 million liters/day), agriculture and pisciculture in these regions produce 150 tons of fresh vegetables and 40 tons of fish daily providing an employment opportunity of 2 persons per hectare. Tiny microbes and plankton are instrumental in turning wastes into wealth, with the support of the strong solar radiation, and a myriad of physico-chemical interactions and transformations.

\section{ACKNOWLEDGEMENT}

Authors thankfully acknowledge AICTE and UGCMRP for financial supports. One of the authors (AR) also expresses gratitude to the UGC for Junior Research Fellowship. Authors are also thankful to the Director of Technical Education and the Director of Public Instructions, Govt. of West Bengal, India for cooperation and necessary infrastructural support.

\section{REFERENCES}

Ahlstorm, E.H. 1940. Revision of Rotatoria, Genus Brachionus and Platyias with descriptions of one new species and two new varieties.

Arora, H.C. 1961. Rotifera as indicators of pollution, Bull. CPHERI Nagpur, 3\&4: 24-26.

Battish, S.K. 1992. Freshwater Zooplankton of India, Oxford and IBH publishing CO, Pvt, Ltd. Delhi.
Chandra, S. \& G. Krishna. 1983, Effect of tannery waste disposal on the quality of the river Ganges in Kanpur. Poll. Res., 2: 63-64.

Chattopadhyay, B., R. Gupta, A. Chatterjee \& S.K. Mukhopadhyay. 1999. Characterisation and ecotoxicity of tannery wastes envisaging environmental impact assessment, J.Amer.Leather Chem. Assoc., 94 (9): 337-346.

Chattopadhyay, B., S. Chatterjee \& S.K Mukhopadhyay. 2004. Seasonality in Physico Chemical; Parameters of Tannery Wastewater Passing Through The East Calcutta Wetland Ecosystem. J. Soc. Leather Technol. Chem., 88: 27-36.

Das, N.K. \& N.C. Datta. 2000. Seasonal variation in diversity indices of periphytic community of wastewater-fed pond, 2000, Waste recycling and resource management in the developing world, University of Kalyani and International ecological engineering society, Kalyani: 10-11.

Eaton, A.D., L.S. Clesceri, A.E. Greenberg. 1995. Standard Methods of the Examination of Water and Wastewater. 19 th. Edn. APHA, Washington D.C.

Edmondson, W.T. Fresh water Biology (Ward \& Whipple). 1992. International Books \& Periodicals Supply Service, $2^{\text {nd }}$ ed.

Forbes, V.E. 1999. Genetics and Ecotoxicology-Insight from the Interface. In: V.E. Forbes (Ed.), Genetics and Ecotoxicology. Taylor \& Francis, U.S.A: 1-8.

Koteswari, Y.N. \& R. Ramanibai. 2004. Evaluation of toxicity of tannery effluent on plankton community structure: a multispecies microcosm study II. Turk J Biol., 28: 55-63.

Michael, P. 1984. Ecological methods for Field and Laboratory Investigation. Tata McGraw Hill Publication Ltd, New Delhi.

Michael, R.G. 1968. Studies on the Zooplankton of a tropical fishpond. Hydrobiol., 32: 47-68.

Mishra, S.R. \& D.N. Saksena. 1992. Eds., Aquatic Ecology, Asish Publication House, Delhi: 231-273.

Mukhopadhyay, S.K., A. Chatterjee, R. Gupta \& B. Chattopadhyay. 2000. Rotiferan community structure of a tannery effluent stabilisation pond in east Calcutta wetland ecosystem. Chem. Env. Res., 9 (1 \& 2): 85-91.

Patil, S.G. \& D.K. Harshey. 1983. Impact of gelatine factory effluent on the water quality and biota of a stream near Jabbalpur, J. Environ. Biol., 7: 61-65.

Saksena, D.N. \& N. Kulkarni. 1986. On the rotifer fauna of two sewage chanels of Gwalior. Limnologica (Berlin), 17: 139148.

Sarma, S.S.S. 1996. Some relationships between size structure and fertility of rotifer populations. In: B.L. Kaul (Ed.), Advances in Fish Wildlife Ecology and Biology. Daya Publishing House, Delhi, 1: 37-50. 
Snell, S.W., M. Serra \& M.J. Carmona. 1999. Toxicity and sexual reproduction in Rotifers: Reduced resting egg production and heterozygosity loss, In: V.E. Forbes (Ed.), Genetics and Ecotoxicology, Taylor \& Francis, U.S.A., 169185.

Sharma, B.K. 1979a. Rotifers of West Bengal III, Hydrobiol., 64: 239-250.

Sharma, B.K. 1979b. Rotifers of West Bengal IV, Hydrobiol., 65: 39-47.

Sharma, B.K. 1986. Assessment of pollution indicators in Indian rotifera, J. Meghalaya Sci. Soc., 9: 47-49.

Sharma, B.K. 1992. Systematics, distribution and ecology of fresh water rotifer of West Bengal. In: S.R. Mishra and

Received: June 2007

Accepted: December 2007
D.N. Saksena (Eds), Aquatic Ecology, Asish Publishing House, Delhi: 231-237.

Sharma, D.C., P.C. Srivastava, B.N. Johri \& P. Chandra. 1996. Environmental Impact of Tannery Effluents on Heavy Metal Phytotoxicity and Health Hazards. J. Indust. Poll. Cont., 12(2): 137-142.

van Groenestijn, J.W., E. Ravindranath \& J.S.A. Langerwerf. 1999. Sulphur recovery from tannery wastewater, Proc. XXV IULTCS Congress, Central Leather Research Institute, Madras: 428-433.

Wetzel, R.G. 2001. Limnology: Lake and River Ecosystems, $3^{\text {rd }}$ Ed. Academic Press, New York: 181-186. 